\title{
Cd-tolerance markers of Pfaffia glomerata (Spreng.) Pedersen plants: anatomical and physiological features
}

\section{Marcelo Pedrosa Gomes ${ }^{1,2 *}$, Teresa Cristina Lara Lanza Sa e Melo Marques ${ }^{3}$, Giordane Augusto Martins ${ }^{4}$, Marília Mercia Lima Carvalho Carneiro², Ângela Maria Soares ${ }^{2}$}

\author{
'Université du Québec à Montréal, Institut des Sciences de l'environnement, Succ. Centre-Ville, Montréal, \\ Québec, Canada. \\ 2Universidade Federal de Lavras, Departamento de Biologia, Lavras, MG, Brazil. \\ ${ }^{3}$ Universidade Federal de Lavras, Departamento de Ciências do Solo, Lavras, MG, Brazil. \\ ${ }^{4}$ Instituto Nacional de Pesquisa da Amazônia, Manaus, AM, Brazil. \\ ॠCorresponding author: marcelopgom@yahoo.com.br
}

Received: 16 December 2012; Accepted: 14 February 2013

\begin{abstract}
Physiological and anatomical features of Cd-tolerance in Pfaffia glomerata were examined by exposing plantlets

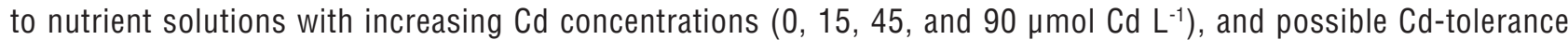
markers were established. Cd contents were found to be higher in roots than in shoots. According to the bioconcentration factor data, this species is effectively a $\mathrm{Cd}$-hyperaccumulator, as previously attested. $\mathrm{Cd}$ induced the appearance of xeromorphic characteristics in leaves (decreased water potential, increased numbers and decreased stomata size) and increased root endodermis thickness. The enzymatic antioxidant systems of roots and leaves were differently affected by $\mathrm{Cd}$. The coordinated activities of antioxidant enzymes were effective in reducing $\mathrm{Cd}$-induced reactive oxygen species in plants, mainly in leaves. Root endodermis thickness, stomatal size and numbers, root superoxide dismutase, and guaiacol peroxidase, as well as leaf guaiacol peroxidase and catalase activities can all be considered Cd-tolerance markers in Pfaffia glomerata. Due to its high root Cd accumulation, Pfaffia glomerata may be useful in $\mathrm{Cd}$-phytoextraction programs, however the pharmacological use of plants grown in the presence of $\mathrm{Cd}$ must be avoided.
\end{abstract}

Keywords: adaptation, Cd-oxidative damage, phytoextraction, tolerance. 


\section{INTRODUCTION}

Water and soil contamination by heavy metals is a growing environmental issue around the world. Although traces of heavy metals are natural soil components, human activities such as mining and agriculture are contributing to toxic ion accumulation in the environment (Kabata-Pendias and Pendias, 2001). The heavy metal contamination of soils in Brazil is directly linked to anthropogenic activities, especially mining and modern agricultural techniques that can leave hazardous metal residues in the environment (Kabata-Pendias and Pendias, 2001), which demand effective remediation. Among the heavy metals, cadmium $(\mathrm{Cd})$ is of particular interest for its universal toxicity even at low concentrations (Das et al., 1997), making the restoration of $\mathrm{Cd}$-contaminated areas very important. This element has high mobility and is not known to have any metabolic role in plants or animals (Barceló et al., 1990).

Phytoremediation is currently one of the most effective environmental reclamation techniques available and has been widely used. This is ecologically friendly and costeffective, with a potential market in countries such as Brazil, which have numerous metallic ore resources. Although native vegetation types growing on naturally mineralized or metal-contaminated sites have been described in Brazil, relatively few potential phytoremediator species were also identified (Ginocchio and Baker, 2004). Carneiro et al. (2002) reported high growth rates and apparent tolerance of the species of genus Pfaffia to soils contaminated with $\mathrm{Cd}$ and $\mathrm{Zn}$ (90 and $1,450 \mathrm{mg} \mathrm{kg}^{-1}$ respectively), and Skrebsky et al. (2008), Calgaroto et al. (2010), and Gupta et al. (2011) demonstrated reasonable degrees of $\mathrm{Cd}, \mathrm{Hg}$, and $\mathrm{Pb}$ tolerances in Pfaffia glomerata (Spreng.) Pedersen. Authors reported biochemical-antioxidant system activations in the presence of heavy metals that were related to fundamental features of plant survival.

Pfaffia glomerata are perennial subshrubs or shrubs usually found growing at the edges of woods or rivers and in the Brazilian rupestrian field (Nascimento et al., 2007). This species belongs to the family Amaranthaceae and has high commercial pharmaceutical value (Montanari Jr., 1999), as its roots are used as aphrodisiacs, stimulants, and to treat diabetes and inflammatory diseases (Oliveira et al., 1980). Several economically important compounds have also been isolated and identified from the roots of Pfaffia glomerata (De Paris et al., 2000). Due to the intense predatory exploitation of natural sources of this species, its cultivation has been increasingly stimulated (Montanari Jr., 1999), so that the use of Pfaffia glomerata in environmental recuperation programs could represent an interesting strategy for both environmental recovery and economic development.

Many phytoremediation studies have reported changes in the anatomical and physiological characteristics of plants as a consequence of their adaption to heavy metal-induced environment stress (Barceló et al., 1990; Monni et al., 2001). Researches into the features associated with heavy metal tolerance are important for our understanding of the processes involved in this phenomenon, and for selecting characteristics that could facilitate the identification of potential phytoremediator species. Therefore, the present study evaluated Cd-tolerance at both physiological and anatomical levels in Pfaffia glomerata seedlings grown under increasing $\mathrm{Cd}$ concentrations in nutrient solution, and Cd-tolerance markers were established. We also investigated $\mathrm{Cd}$ uptake and distribution in this plant, and its classification as a Cd-hyperaccumulator species (Carneiro et al., 2002) was revised.

\section{MATERIAL AND METHODS}

Plant growth and physiological analyses: Pfaffia glomerata seeds obtained at the Federal University of Mato Grosso do Sul (UFMS) were germinated in Styrofoam trays containing sterile vermiculite in a thermostat-controlled dark chamber $(70 \%$ relative humidity and $25^{\circ} \mathrm{C}$ ). The seedlings were then transferred to a greenhouse for 45 days (at 15 to $31^{\circ} \mathrm{C}$; with $825 \mu \mathrm{mol} \mathrm{m} \mathrm{m}^{-2} \mathrm{~s}^{-1}$ average photosynthetically active radiation). Seedlings with similar size and weights were later transferred to plastic beakers (six-liter capacity, two plants per beaker) containing Clark's nutrient solution (Clark, 1975). After an initial growth period of 15 days, the most vigorous seedlings were selected and $\mathrm{Cd}$ was added $\left(\mathrm{as} \mathrm{CdSO}_{4}\right.$ ) to the nutrient solution at different concentrations: $0,15,45$, and $90 \mu \mathrm{mol} \mathrm{L}^{-1}$. The solutions were continuously aerated and renewed weekly. $\mathrm{Cd}$ concentrations used in this work were chosen based on Carneiro et al. (2002). The $\mathrm{pH}$ of the medium was checked and adjusted on a daily basis to $5.5 \pm 0.1$. The plants were exposed to $\mathrm{Cd}$ for 20 days.

Chlorophylls $a$ and $b$ were quantified according to Arnon (1949), and the carotenoid content referring to Duke and Kenyon (1986). $\beta$-carotene was quantified using the $2,500 \mathrm{~L} \mathrm{~mol}^{-1} \mathrm{~cm}^{-1}$ molar absorptivity coefficient (Sandmann and Böger, 1983). One fully expanded leaf 
per experimental unit was used for pigment analysis, with five replicates per treatment; both water status and pigment contents were evaluated after 20 days of treatment with $\mathrm{Cd}$. The water status of fully expanded leaves from the third or fourth nodes was assessed in the early morning by measuring their water potential ( $\Psi_{w}$ maximum), with the aid of a pressure chamber (Soil Moisture Equipment Corp - Model 3005, Santa Barbara, CA, USA).

After 20 days of $\mathrm{Cd}$ treatment, the plants were harvested and separated into roots and shoots, stored in paper bags, and dried to a constant weight in a forced-air circulation oven at $70^{\circ} \mathrm{C}$ in order to determine biomass production.

Plant cadmium concentration: $\mathrm{Cd}$ concentrations in the roots and shoots were determined by atomic absorption spectrophotometry (Perkin-Elmer Analyst 400 ) after a $0.1 \mathrm{~g}$ wet digestion of dried material in $5 \mathrm{~mL}$ of a strong acid solution $-\mathrm{HNO}_{3} / \mathrm{HClO}_{4}, 3: 1, \mathrm{v} \mathrm{v}^{-1}$ (Van Assche et al., 1990). Cd affecting plant growth was verified by its critical dose solution values of $\mathrm{CDS}_{10}$ and $\mathrm{CDS}_{50}$, which promoted decreases of 10 and $50 \%$ in plant yield respectively, and Cd-toxicity levels (TCL - Cd-concentrations in shoots that promoted $10 \%$ decreases in shoot yields). Cd transport between plant tissues was verified by the primary transport index (PTI) calculated as the ratio of its concentration in the shoots and roots (Moral et al., 1994). In order to study $\mathrm{Cd}$ uptake and bioconcentration behavior, the following indices were used: bioconcentration factor (BCF), calculated by dividing the $\mathrm{Cd}$-concentration in plant tissues (ppm) at harvest by the metal one $\left(\mathrm{mg} \mathrm{g}^{-1}\right.$ of dry weight - DW) in the solution (Sharma and Agrawal, 2006); total accumulation rate - TAR (mg plant ${ }^{-1} \mathrm{~d}^{-1}$ ) was determined following Zhu et al. (1999), and Cd uptake (mg plant $\left.{ }^{-1} \mathrm{~d}^{-1}\right)$ following Sharma and Agrawal, (2006). TAR and total Cd uptake were calculated using the following formulas:

$$
\begin{aligned}
& T A R=\frac{\text { root Cd content }+ \text { shoot } \mathrm{Cd} \text { content }}{(\text { total } \mathrm{dry} \text { matter } \times \mathrm{T})} \\
& \text { Uptake }=\frac{\text { total Cd content }}{T}
\end{aligned}
$$

where,

T: experimental period (20 days).

Light microscopy: Anatomical analyses were performed at the end of the experimental period
(20 days after initiating the $\mathrm{Cd}$-treatment). Root samples were collected and fixed for 48 hours in Karnovsky's fixative solution $(2.5 \%$ glutaraldehyde and $2.5 \%$ paraformaldehyde), dehydrated in a graded ethanol series, and included in butanol/plastic resin (Historesin, Laica). Semi-thin sections (5 to $8 \mu \mathrm{m}$ thick) were prepared using a Jung AG rotary microtome, stained with toluidine blue (equal volumes of $0.3 \%$ of basic toluidine and $1 \%$ sodium tetraborat). Fully expanded leaves were collected for leaf anatomical studies, fixed in FAA (formaldehyde + acetic acid $+70 \%$ ethyl alcohol 5:5:90 v/v/v) (Johansen, 1940) during 72 hours and then stored in $70 \%$ ethyl alcohol. Paradermal sections were manually prepared from the mid third of abaxial epidermis of leaves and stained with a $1 \%$ safranine solution. All slides were examined and photographed using a Ken-a-Vision TT18 light microscope equipped with a Canon Power Shot A620 digital camera. Measurements of the anatomical characteristics were made using Sigma Scan Pro 4.0 for Windows (SPSS, Inc., Chicago, IL, USA). The items assessed in the root system were done in the root hair zone and included epidermis and endodermis thickness. Stomatal density was defined as the number of stomata per $\mathrm{mm}^{2}$; the areas of the stomata were calculated using the formula for the area of an ellipse ( $\pi \mathrm{ab})$ and are given in $\mu \mathrm{m}^{2}$ after measuring the polar (a) and equatorial (b) diameters of each stomata (Lawson et al., 1988). A minimum of five samples was examined for each $\mathrm{Cd}$ treatment.

Oxidative damage and antioxidantenzymes: $0 x$ idative damage was estimated in terms of lipid peroxidation based on the production of 2-thiobarbituric acid (TBA)reactive metabolites, particularly malondialdehyde (MDA), following the methods of Heath and Packer (1968) and Buege and Aust (1978). Measurements of MDA were performed as in Hodges et al. (1999), which takes into account the possible influence of interfering compounds in the assay for the TBA-reactive substances. Readings were taken using a spectrophotometer at 535 and $600 \mathrm{~nm}$, and the MDA concentrations were expressed as nmol gof fresh tissue.

Antioxidant enzymes were extracted by macerating $200 \mathrm{mg}$ of fresh leaves and roots in $800 \mu \mathrm{L}$ of an extraction buffer containing $100 \mathrm{mmol} \mathrm{L}^{-1}$ potassium phosphate buffer $(\mathrm{pH}=7.8), 100 \mathrm{mmol} \mathrm{L}^{-1}$ EDTA, and $1 \mathrm{mmol} \mathrm{L} \mathrm{L}^{-1} \mathrm{~L}$-ascorbic acid. The protein contents of all of samples were determined using Bradford's method. Superoxide dismutase - SOD (EC 1.15.1.1) activity was measured photometrically at $560 \mathrm{~nm}$, based on the inhibition by SOD of nitrobluetetrazolium (NBT) reduction. One unit of SOD was defined as the 
amount needed to bring about a $50 \%$ inhibition of the NBT reduction state (Beyer and Fridovich, 1987). Catalase - CAT (EC 1.11.1.6) activity was measured photometrically at $240 \mathrm{~nm}$ as described by Kraus et al. (1995), with minor alterations as described by Azevedo et al. (1998), through the determination of the rate of conversion from $\mathrm{H}_{2} \mathrm{O}_{2}$ to $\mathrm{O}_{2}$. Total ascorbate peroxidase - APX (EC 1.11.1.11) activity was measured as the decrease in absorbance at $290 \mathrm{~nm}$, resulting from ascorbate oxidation (Nakano and Asada, 1981). Guaiacol peroxidase - GPX (EC 1.11.1.7) activity was achieved photometrically at $470 \mathrm{~nm}$ (Souza and MacAdam, 1998) by measuring tetraguaiacol formation at $28{ }^{\circ} \mathrm{C}$. Concerning the glutathione reductase GR (EC 1.6.4.2), it was determined as described by Cakmak and Horst (1991) by measuring the decrease in absorbance at $340 \mathrm{~nm}$ due to NADPH oxidation.

Statistical analyses: All measurements were performed on five replicate plants per treatment. Data were analyzed for statistical significance using a one-way analysis of variance (ANOVA). When any effects were significant $(p \leq 0.05)$, differences between means were evaluated using Scott-Knott's test. Regression analyses were also performed to test for relationships between the variables, using the software Sigma-Plot 11.0 (Systat Software Inc., USA).

\section{RESULTS}

Plant growth and visual symptoms: While shoot DW was not significantly affected $(p>0.05)$ by $\mathrm{Cd}$ doses administered in solution, root DW decreased in plants at both of the highest $\mathrm{Cd}$ concentrations (Figure 1). Reduction of 33.3 and $44.4 \%$ were seen in the roots of 45 and $90 \mu \mathrm{mol} \mathrm{Cd} \mathrm{L}{ }^{-1}$ treated plants. Total biomass production did not significantly differ ( $p>0.05)$ among the different treatments (Figure 1). Plants growing in the highest $\mathrm{Cd}$ concentrations showed wilting and yellowing of leaves and blackening of their roots by the end of the experimental period.

Pigment content: Decreases in chlorophyll a content and increasing levels of $b$ were observed in plants exposed to the highest $\mathrm{Cd}$ concentrations $(p<0.05)$, as seen in Table 1 . Moreover, between the $\mathrm{Cd}$-treated plants, the $\beta$-carotene levels were greater in

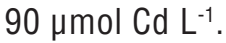

Cadmium concentration and plant responses: $A$ regression curve was used to establish the relationship

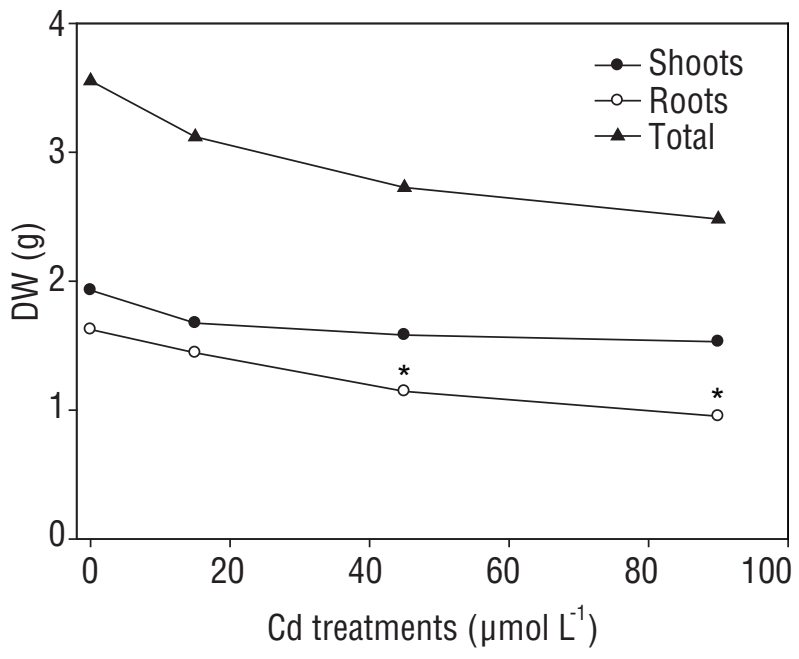

Figure 1. Shoot, root, and total dry weight (DW) of 60-day-old Pfaffia glomerata plants cultivated during 20 days in nutritive

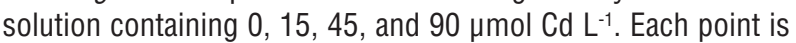
the mean of five measurements. * significant by the Scott-Knott's test $(p<0.05)$.

Table 1. Pigment content ( $\mathrm{mg} \mathrm{g}^{-1}$ of fresh weight), and water status (MPa) of 60-days-old Pfaffia glomerata plants cultivated during 20 days in nutritive solution containing $0,15,45$, and

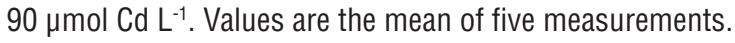

\begin{tabular}{lrrrr}
\hline & \multicolumn{4}{c}{ Cd doses $\left(\mathbf{m m o l ~ L}^{-1}\right)$} \\
\cline { 2 - 5 } & \multicolumn{1}{c}{$\mathbf{1 5}$} & $\mathbf{4 5}$ & $\mathbf{9 0}$ \\
\hline Chlorophyll $\mathrm{a}$ & $1.33 \mathrm{a}$ & $1.26 \mathrm{a}$ & $1.39 \mathrm{a}$ & $0.48 \mathrm{~b}$ \\
Chlorophyll $b$ & $0.43 \mathrm{~b}$ & $0.43 \mathrm{~b}$ & $0.47 \mathrm{~b}$ & $0.87 \mathrm{a}$ \\
Carotenoids & $49.67 \mathrm{a}$ & $40.80 \mathrm{~b}$ & $41.01 \mathrm{~b}$ & $48.72 \mathrm{a}$ \\
$\Psi_{\mathrm{w}}$ maximum & $-0.36 \mathrm{a}$ & $-0.46 \mathrm{~b}$ & $-0.46 \mathrm{~b}$ & $-0.66 \mathrm{c}$ \\
\hline
\end{tabular}

Several letters within the same line indicate significant differences (Scott-Knott, $p<0.05$ ).

between $\mathrm{Cd}$ concentrations in the roots $\left(r^{2}=0.99\right)$ and shoots $\left(r^{2}=0.93\right)$ and those in the nutrient solutions (Figure 2). The $\mathrm{Cd}$ levels of the roots and shoots increased as $\mathrm{Cd}$ exposure increased (Figure 2). Increases of 6,829 and $9,266 \%$ in $\mathrm{Cd}$ concentrations were seen in shoots and roots in relation to the control, respectively, at the highest $\mathrm{Cd}$ exposures. These were always higher in roots than in shoots, regardless of the $\mathrm{Cd}$ solution concentrations, and the former showed marked increases as $\mathrm{Cd}$ exposure increased (Figure 2). Those from the shoots, by contrast, presented only small increases as $\mathrm{Cd}$ exposure increased (Figure 2). 
The Cd-critical dose (CDS) and the Cd-toxicity level (TCL) were determined from regression curves. The

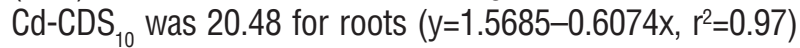
and $47.92 \mathrm{mmol} \mathrm{L}^{-1}$ for shoots $(\mathrm{y}=1.8912-0.0038 \mathrm{x}$, $\left.\mathrm{r}^{2}=0.72\right), 50 \%$ shoot and root yield reductions $\left(\mathrm{Cd}^{-} \mathrm{CDS}_{50}\right)$ were not observed. The TCL Pfaffia glomerata was approximately $129 \mathrm{mg} \mathrm{g}^{-1}$ DW ( $\mathrm{y}=1.8632-0.0015 \mathrm{x}$; $\left.r^{2}=0.84\right)$.

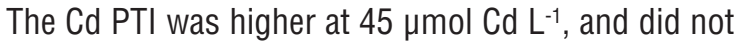
differ among the other $\mathrm{Cd}$ treatments (Table 2). The BCF of the shoots decreased at the highest $\mathrm{Cd}$ concentration (Table 2), and that of the roots had the same result, but

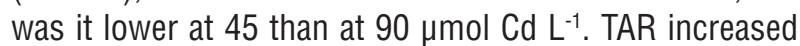
as $\mathrm{Cd}$ exposure was superior (Table 2). As expected, $\mathrm{Cd}$ uptake was higher in the presence of $\mathrm{Cd}$ than in controls, and increased as $\mathrm{Cd}$ concentrations in the nutrient solution increased (Table 2).

Root and leaf anatomical responses: Quantitative anatomical changes were observed in the root tissues of Pfaffia glomerata in response to Cd levels (Table 3). Root epidermis and endodermis thicknesses were higher in the roots of plants exposed to 90 $\mu \mathrm{mol} \mathrm{Cd} \mathrm{L^{-1 }}(p<0.05)$, but no changes were seen in terms of root diameters (Table 3 ). The relationships between endodermal thickness/shoot and root $\mathrm{Cd}$ contents (Figure 3 ) suggested a possible role of the endodermis in limiting $\mathrm{Cd}$ translocation to shoots at exposure levels above $42 \mu \mathrm{mol} \mathrm{Cd} \mathrm{L-1}$ (Figure 3); above this exposure the slope of the curve relating shoot $\mathrm{Cd}$ content and $\mathrm{Cd}$ doses decreased (Figure 2), corroborating this hypothesis.

Stomatal area decreased and stomata density increased as external $\mathrm{Cd}$ concentrations increased (Figure 4a).

Water status: The water status of Pfaffia glomerata decreased in the presence of $\mathrm{Cd}$ and was lower in plants with the highest $\mathrm{Cd}$-exposure levels (Table 1). Decreases in stomatal areas associated with increasing stomatal densities were correlated with decreasing water status of the plants (Figure 4b).

Antioxidant enzyme activities: MDA level increased significantly in roots of plants exposed to $\mathrm{Cd}$ and in

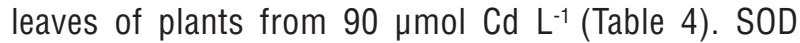
activity increased in the roots, but did not significantly change in the leaves as Cd exposure increased ( $p>0.05)$, as seen in Table 4. Initial increases in root SOD activity

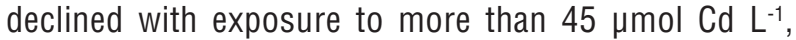
however they still remained higher than the control.

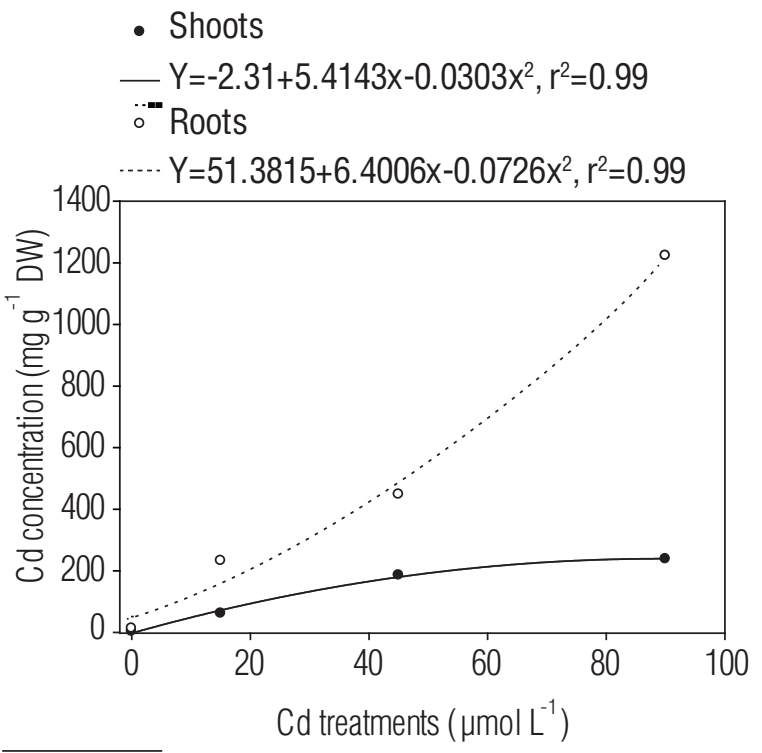

Figure 2. Relationships between the $\mathrm{Cd}$ concentrations of the roots and shoots and Cd treatments in 60-day-old Pfaffia glomerata plants cultivated during 20 days in nutritive solution

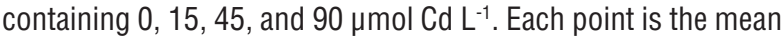
of five measurements.

Table 2. Primary transport index (PTI), shoot and root bioconcentration factors (BCF), total accumulation rate (TAR), and $\mathrm{Cd}$ uptake in 60-days-old Pfaffia glomerata plants cultivated during 20 days in nutritive solution containing $0,15,45$, and

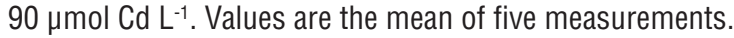

\begin{tabular}{lcrrr}
\hline & \multicolumn{4}{c}{ Cd doses $\left(\mathbf{m m o l ~ L}^{-1}\right)$} \\
\cline { 2 - 5 } & $\mathbf{0}$ & \multicolumn{1}{c}{$\mathbf{1 5}$} & \multicolumn{1}{c}{$\mathbf{4 5}$} & \multicolumn{1}{c}{$\mathbf{9 0}$} \\
\hline Cd PTI & $0.28 \mathrm{~b}$ & $0.26 \mathrm{~b}$ & $0.41 \mathrm{a}$ & $0.19 \mathrm{~b}$ \\
Shoot BCF & - & $36.66 \mathrm{a}$ & $36.70 \mathrm{a}$ & $23.52 \mathrm{~b}$ \\
Root BCF & - & $138.02 \mathrm{a}$ & $88.59 \mathrm{c}$ & $120.92 \mathrm{~b}$ \\
TAR $\left(\mathrm{mg} \mathrm{g}^{-1} \mathrm{~d}^{-1}\right)$ & $0.39 \mathrm{~d}$ & $9.25 \mathrm{c}$ & $14.91 \mathrm{~b}$ & $31.23 \mathrm{a}$ \\
Cd Uptake $\left(\mathrm{mg} \mathrm{g}^{-1} \mathrm{~d}^{-1}\right)$ & $1.39 \mathrm{c}$ & $22.08 \mathrm{~b}$ & $40.32 \mathrm{~b}$ & $77.87 \mathrm{a}$ \\
\hline
\end{tabular}

Different letters within the same line indicate significant differences (Scott-Knott, $p<0.05)$.

The CAT levels in leaves responded differently to MDA,

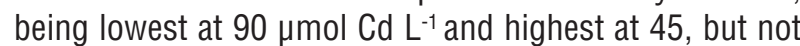
significantly different from 0 (control) or $15 \mu \mathrm{mol} \mathrm{Cd} \mathrm{L^{-1 }}$ (Table 4). Roots, on the other hand, showed the highest CAT levels with the most superior $\mathrm{Cd}$ exposure, and lower levels in plants exposed to the $45 \mu \mathrm{mol} \mathrm{Cd} \mathrm{L^{-1 }}$ treatment (Table 4).

Low APX levels were also seen in roots in the $45 \mu \mathrm{mol} \mathrm{Cd} \mathrm{L^{-1 }}$ treatment, while APX ones in the leaves 


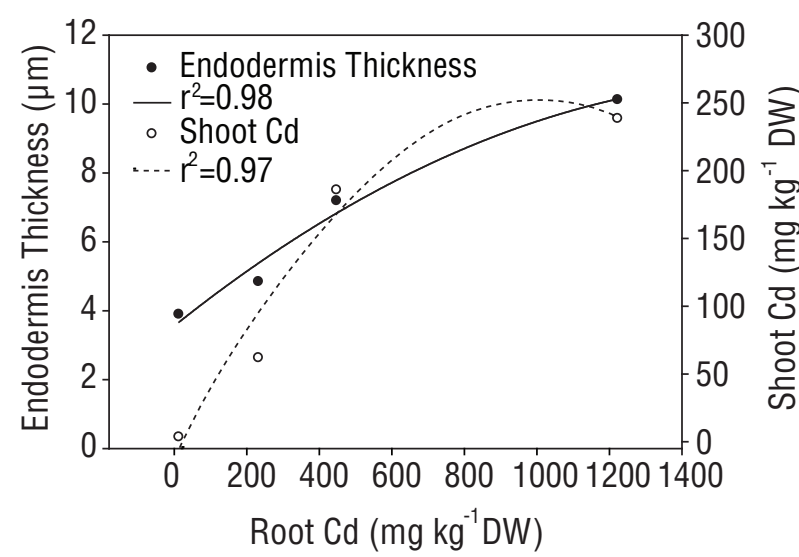

Figure 3. Relationships between endodermal thicknesses and shoot and root Cd concentrations of 60-day-old Pfaffia glomerata plants cultivated during 20 days in nutritive solution containing

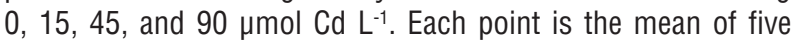
measurements.

Table 3. Anatomical characteristics of 60-day-old Pfaffia glomerata plants cultivated during 20 days in nutritive solution containing $0,15,45$, and $90 \mu \mathrm{mol} \mathrm{Cd} \mathrm{L^{-1 }}$. Values are the mean of five measurements.

\begin{tabular}{|c|c|c|c|c|}
\hline & \multicolumn{4}{|c|}{ Cd doses (mmol L-1) } \\
\hline & 0 & 15 & 45 & 90 \\
\hline \multicolumn{5}{|l|}{ Root tissues } \\
\hline Epidermis (mm) & $7.63 \mathrm{~d}$ & $9.21 \mathrm{c}$ & $13.28 \mathrm{~b}$ & $16.80 \mathrm{a}$ \\
\hline Endodermis (mm) & $3.89 \mathrm{c}$ & $4.84 \mathrm{c}$ & $7.18 b$ & $10.11 \mathrm{a}$ \\
\hline Root diameter (mm) & 147.19 & 146.19 & 146.52 & 147.84 NS \\
\hline \multicolumn{5}{|l|}{ Stomata } \\
\hline $\begin{array}{l}\text { Stomata density } \\
\text { (number/mm²) }\end{array}$ & $83.75 \mathrm{c}$ & $107.25 \mathrm{~b}$ & $120.50 \mathrm{a}$ & $117.25 \mathrm{a}$ \\
\hline $\begin{array}{l}\text { Stomata surface } \\
\text { area }\left(\mathrm{mm}^{2}\right)\end{array}$ & \multicolumn{4}{|c|}{$2,665.57$ a $1,500.86$ b $1,067.33$ b 1,239.32 b } \\
\hline
\end{tabular}

Different letters within the same line indicate significant differences (Scott-Knott, $p<0.05)$. NS: nonsignificant.

did not statistically differ among the different treatments (Table 4). GPX activity decreased in roots

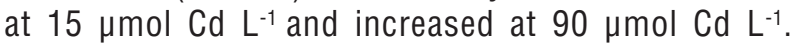
GPX levels in the leaves increased in the highest $\mathrm{Cd}$ treatments (Table 4). GR activity in the roots decreased in response to higher $\mathrm{Cd}$ exposure, while its activity increased in the leaves with the same exposures (Table 4).
A

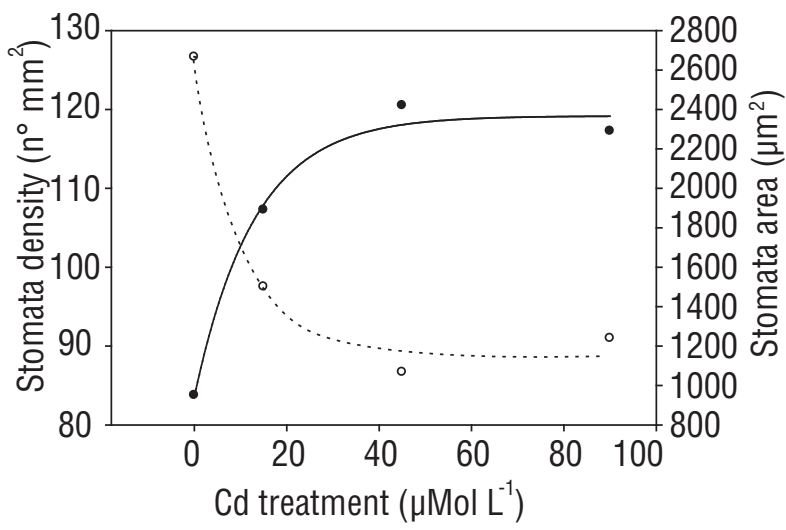

- Stomata density

$-\mathrm{Y}=83.60+35.57 e^{0.08 x} \quad r^{2}=0.98$

- Stomata area

$\cdots Y=2667.69+1516.48 e^{-0.10 x} r^{2}=0.99$

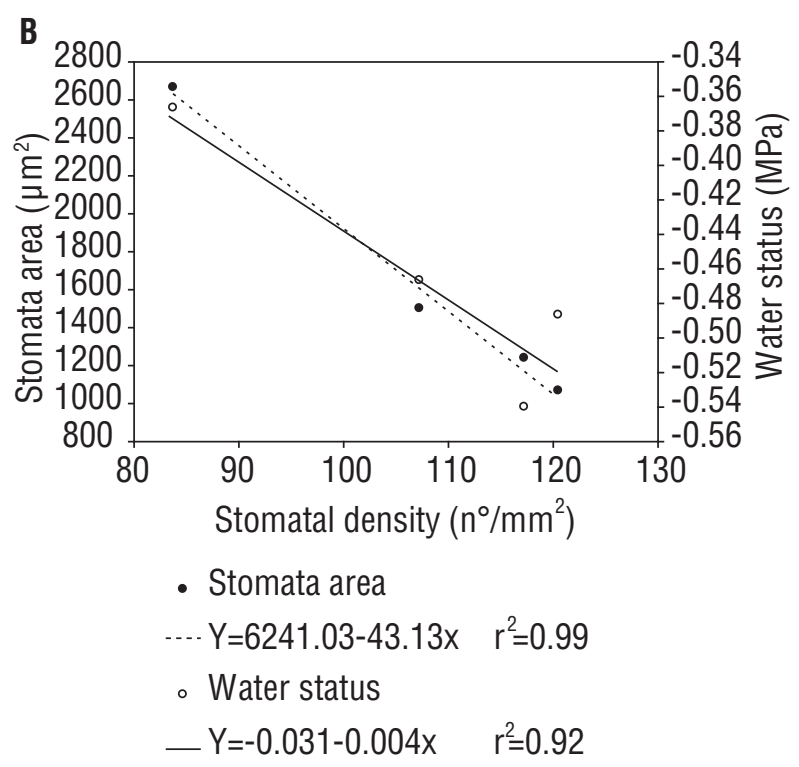

Figure 4. Relationships between stomatal densities and surface areas and $\mathrm{Cd}$ exposure (a) and between stomatal surface area, stomatal density, water status and the stomata densities (b) of 60-day-old Pfaffia glomerata plants cultivated during 20 days

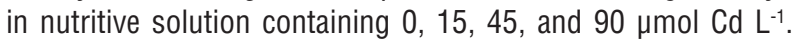
Each point is the mean of five measurements.

\section{DISCUSSION}

Cd tolerance and uptake by Pfaffia glomerata: Deleterious effects of $\mathrm{Cd}$ on the growth of Pfaffia glomerata plants were only observed at the highest medium Cd concentrations. Roots showed consistently 
Table 4. Lipid peroxidation (MDA) and activities of superoxide dismutase (SOD), catalase (CAT), ascorbate peroxidase (APX), guaiacol peroxidase (GPX) and glutathione reductase (GR) in the roots and leaves of 60-day-old Pfaffia glomerata plants cultivated during 20 days

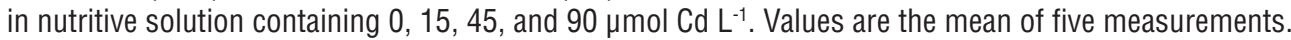

\begin{tabular}{|c|c|c|c|c|c|c|}
\hline \multirow{2}{*}{$\begin{array}{l}\mathrm{Cd} \\
\left(\mathrm{mmol} \mathrm{L}^{-1}\right)\end{array}$} & MDA & SOD & CAT & APX & GPX & GR \\
\hline & $\left(\mathrm{nmol} \mathrm{MDA} \mathrm{g}^{-1} \mathrm{FW}\right)$ & $\left(\mathrm{Umg}^{-1}\right.$ protein $)$ & $\begin{array}{c}\left(\mathrm{mmol} \mathrm{H}_{2} \mathrm{O}_{2} \mathrm{mg}^{-1}\right. \\
\left.\text { protein } \mathrm{min}^{-1}\right)\end{array}$ & $\begin{array}{l}\text { (mmol Ascorbate } \\
\left.\mathrm{mg}^{-1} \text { protein } \mathrm{min}^{-1}\right)\end{array}$ & $\begin{array}{c}\text { (mmol Guaiacol } \\
\left.\mathrm{mg}^{-1} \text { protein } \mathrm{min}^{-1}\right)\end{array}$ & $\begin{array}{c}\text { (mmol NADPH mg-1 }^{-1} \\
\left.\text { protein } \text { min }^{-1}\right)\end{array}$ \\
\hline \multicolumn{7}{|l|}{ Roots } \\
\hline 0 & $27.30 \mathrm{C}$ & $1.26 \mathrm{~d}$ & $0.33 \mathrm{~b}$ & $7.65 \mathrm{c}$ & $9.35 b$ & $1.32 \mathrm{a}$ \\
\hline 15 & $37.43 \mathrm{~b}$ & $5.86 \mathrm{a}$ & $0.29 b$ & $8.62 \mathrm{~b}$ & $8.05 \mathrm{c}$ & $0.53 b$ \\
\hline 45 & $44.62 \mathrm{a}$ & $4.75 b$ & $0.20 \mathrm{C}$ & $4.94 \mathrm{~d}$ & $9.57 \mathrm{~b}$ & $0.44 \mathrm{~b}$ \\
\hline 90 & $48.36 \mathrm{a}$ & $3.55 \mathrm{c}$ & $0.49 \mathrm{a}$ & $9.40 \mathrm{a}$ & $10.20 \mathrm{a}$ & $0.58 \mathrm{~b}$ \\
\hline \multicolumn{7}{|l|}{ Leaves } \\
\hline 0 & $144.45 b$ & 5.49 & $0.79 \mathrm{~b}$ & 2.36 & $0.82 \mathrm{c}$ & $0.50 \mathrm{c}$ \\
\hline 15 & $137.72 \mathrm{~b}$ & 8.23 & $0.84 b$ & 3.94 & $0.74 \mathrm{c}$ & $0.52 \mathrm{c}$ \\
\hline 45 & $129.07 \mathrm{~b}$ & 6.33 & $1.00 \mathrm{a}$ & 3.38 & $1.00 \mathrm{~b}$ & $0.76 \mathrm{~b}$ \\
\hline 90 & $298.81 \mathrm{a}$ & $6.91 \mathrm{NS}$ & $0.60 \mathrm{c}$ & $3.28 \mathrm{NS}$ & $1.60 \mathrm{a}$ & $0.95 \mathrm{a}$ \\
\hline
\end{tabular}

Different letters within the same column indicate significant differences (Skott-Knott, $p<0.05)$. NS: nonsignificant.

higher $\mathrm{Cd}$ contents than shoots (Figure 2) as they came into more direct contact with $\mathrm{Cd}$ in nutrition solution, and therefore they were presumably more subject to the toxic effects of that heavy metal. Additionally, it is known that roots have a defensive role in protecting aboveground plant organs from heavy metal exposure (Mazhoudi et al., 1997). Nonetheless, the Cd-tolerance of Pfaffia glomerata is supported by their high $\mathrm{Cd}_{-} \mathrm{CDS}_{10}$ and by the absence of $50 \% \mathrm{Cd}$-induced yield reductions. Shoot and root $\mathrm{CDS}_{10}$ values were 47.92 and $20.48 \mathrm{mmol} \mathrm{Cd} \mathrm{L}^{-1}$, respectively, and they were much higher than those reported for other plants considered to be Cd-tolerant and used in $\mathrm{Cd}$-phytoremediation programs in Brazil.

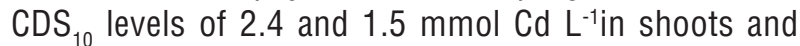
9.0 and $6.4 \mathrm{mmol} \mathrm{Cd} \mathrm{L}^{-1}$ in roots were reported for Eucalyptus maculate and E. urophylla, respectively (Soares et al., 2005); shoot CDS $_{10}$ in Cedrela fissilis was reported to be $6.7 \mathrm{mmol} \mathrm{L}^{-1}$ (Paiva et al., 2000). The $\mathrm{CDS}_{10}$ of Pfaffia glomerata was about four to nine times higher than seen in these other species. $\mathrm{CDS}_{10}$ levels similar to Pfaffia glomerata were reported in the native Brazilian tree Tabebuia impetiginosa (Paiva et al., 2000 ), indicating the potential value of native species in phytoremediation programs. In addition to relatively small decreases in biomass and its high $\mathrm{CDS}_{10}$ value, the Cd-tolerance of Pfaffia glomerata was accompanied by a higher TCL (129 $\mathrm{mg} \mathrm{g}^{-1}$ shoot DW). In species that are highly sensitive to this heavy metal, such values tend to range from 5 to $10 \mathrm{mg} \mathrm{Cd} \mathrm{g}^{-1}$, while tolerant species show those from 50 to $200 \mathrm{mg} \mathrm{Cd} \mathrm{g}^{-1}$ (Kabata-Pendias and Pendias, 2001).

Visual symptoms like growth and biomass reductions and morphological alterations in roots are commonly seen in plants growing under toxic heavy metal conditions, and occur even in tolerant or accumulator species (Gomes et al., 2011). The wilting and yellowing of leaves seen in plants at the highest $\mathrm{Cd}$ exposures are linked to $\mathrm{Cd}$-induced decreases in both water potential and chlorophyll a biosynthesis (Table 1). Water balance disturbances have been reported in plants under heavy metal stress (Barceló et al., 1990; Wójcik et al., 2005), probably due to changes in size and number of xylem vessels resulting from alterations in plant hormonal balances (Poschenrieder and Barceló, 1999). Heavy metal effects on chlorophyll biosynthesis related to changes in $\delta$-ALA-D enzyme activity have been reported (Skrebsky et al., 2008), and decreased water potentials and resulting tissue dehydration were also related to decreased $\delta$-ALA-D activity (Singh et al., 1997), which catalyzes the condensation of two molecules of $\delta$-aminolevulinic acid - ALA to porphobilinogen (Gibson et al., 1955). Nevertheless, at least to the studied time, reductions in plant water status and chlorophyll levels apparently did not provoke exaggerated effects on the photosynthetic system of Pfaffia glomerata as those plants did not show any detectable reductions in shoot biomass production. We also observed that between $\mathrm{Cd}$ treated plants, carotenoid contents were greater in those of the highest $\mathrm{Cd}$ exposure (Table 1), as well as these plants showed increased MDA levels (Table 4). Increases in carotenoid levels have been found to be related to increasing oxidative stress in plants, thus aiding them in avoiding major deleterious effects on photosynthesis (Singh et al., 2006).

Plants growing on contaminated substrates tend to concentrate $\mathrm{Cd}$ in their roots, and when $\mathrm{Cd}$ concentrations in the growth medium increase, metal concentrations in the roots can exceed shoot contents by more than 100- 
fold (Kabata-Pendias and Pendias, 2001), as it was seen in the present study. Indeed, we verified a pronounced increase of $\mathrm{Cd}$ concentration in roots than in shoots of $\mathrm{Cd}$ treated plants compared to control, mainly from the highest $\mathrm{Cd}$ dose $(9,266 \%$ in roots and $6,829 \%$ in shoots - Figure 2). One of the heavy metal-tolerance mechanisms of plants functions by decreasing metal translocation to the shoots, thus avoiding exaggerated negative growth effects by reducing heavy metal interference with photosynthetic processes, such as chlorophyll synthesis, chloroplast organization, and PSII activity (Sandalio et al., 2001).

$\mathrm{Cd}$ levels were found to be quite high in the shoots of Pfaffia glomerata (with means $>200 \mathrm{mg}$ per $g$ of dry shoots). The shoot metal concentrations seen in Pfaffia glomerata classified the species as a Cd-hyperaccumulator, as previously reported by Carneiro et al. (2002). Although the BCF is more important than shoot concentrations per se when evaluating the phytoremediation potential of a given species (Zhao et al., 2003). The BCF is typically lower than one in excluding species, whereas that of metal-accumulating species is often greater than it (Baker, 1981). Accordingly, Pfaffia glomerata did conform to the definition of a metal accumulating species, as both its root and shoot BCF levels were greater than 1 (Table 2). However, it decreased as $\mathrm{Cd}$ exposure increased (Table 2). BCF levels generally tend to decrease as substrate metal concentrations increase (Zhao et al., 2003), indicating a diminishing efficiency of heavy metal accumulation with increasing exposure (Zhao et al., 2003). Decreasing BCF levels of both shoots and roots were only seen at doses up to their respective $\mathrm{CDS}_{10}$, indicating that $\mathrm{Cd}$-induced physiological changes (and thus $\mathrm{Cd}$ uptake) happen mainly up to these levels. The higher root BCF seen in plants at the highest $\mathrm{Cd}$ exposures in relation to that seen at $45 \mu \mathrm{mol} \mathrm{Cd} \mathrm{L^{-1 }}$ might mainly be associated with the greater $\mathrm{Cd}$-PTI shown

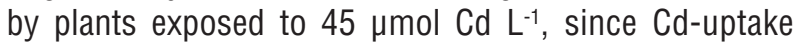
increased as $\mathrm{Cd}$ exposure increased. Furthermore, the increased Cd-uptake may explain the increasing TAR of plants as $\mathrm{Cd}$ exposure increased, as biomass production was only slightly affected.

According to Pence etal. (2000), decreases in BFC may result from the saturation of metal uptake and/or of rootto-shoot transport when internal metal concentrations are high. However, we observed increases in Cd-uptake that, in association with the lack of difference in the PTI

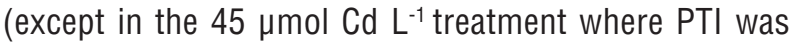
higher), indicated that $\mathrm{Cd}$-uptake was not restricted or saturated in Pfaffia glomerata at substrate concentrations

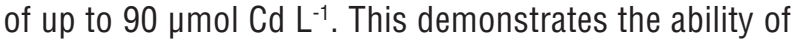

this species to acquire, tolerate, and accumulate $\mathrm{Cd}$ in its tissues. Additionally, species of the genus Pfaffia are characterized by well-developed and bulky tuberous root systems (Marchioretto et al., 2010), and high uptakes and root retentions of $\mathrm{Cd}$ that argue for the use of Pfaffia glomerata in $\mathrm{Cd}$-phytoextraction programs.

Morphological features associated with Cd tolerance in Pfaffia glomerata: Differential Cd tolerance levels observed among several plant species have been attributed to genetic or physiological features, such as the presence of blockers in roots that resulted in $\mathrm{Cd}$ allocation to apoplastic spaces (Marchial et al., 1996). Anatomical alterations in plants are related to changes in physiological processes and plant vigor under heavy metal stress (Lux et al., 2004), and may be associated with their water status and with metal distributions within the plants (Gomes et al., 2011). Roots have shown increased epidermal and endodermal thicknesses in the presence of $\mathrm{Cd}$ (Table 3), which is typical of exposure to heavy metal contamination (Lux et al., 2004; Gomes et al., 2011).

Epidermal thickening may increase negative charge accumulation and biological filtering of metal ions (Gomes et al., 2011). Increasing endodermal thickness (an apoplastic barrier) may lower $\mathrm{Cd}$ translocation to the shoots (Figure 3 ) and decrease its toxic effects on photosynthetic systems, and heavy metal tolerance may be related to the proportion of the root represented by root epidermal and apoplastic barrier tissues (Lux et al., 2004). The chemical modifications of apoplastic barriers and their thickening are important plant adaptations to stress (Enstone et al., 2003), and a number of studies has reported that the endodermis is the most important site of heavy metal accumulation (Ederli et al., 2004; Lux et al., 2004; Wójcik et al., 2005). According to Enstone et al. (2003), this tissue serves as a physiological barrier protecting the plant from various stress factors. As seen under salt-stress, the development of apoplastic barriers (such as the endodermis) has been correlated with increasing resistance to the radial flow of water and solutes in roots, resulting in reduced ion uptakes (i.e. $\mathrm{Na}^{+}$) into the shoots and in better survival under subsequent acute stress (Krishnamurthy et al., 2011).

Cd exposure resulted in the appearance of xeromorphic characteristics in leaves (increased stomatal density but reduced stomata size), probably due to water balance disturbances (Poshchenrieder and Barceló, 1999), and the enhanced accumulation of primary metabolites in the leaves (Lunácková et al., 2003/4). Decreases in the water potentials of Cd treated 
plants were associated with induced xeromorphic characteristics (Figure 4B). The increase in lipid peroxidation activity in leaves (as seen at the highest $\mathrm{Cd}$ doses - Table 4) may have resulted in those in primary metabolites (soluble proteins and lipids) reported by Gupta et al. (2011). Environmental factors have produced a wide variety of adaptations in the leaf anatomies of different taxa (Dickison, 2000) with some features (such as the reduction in stomatal pore area), contributing to reduced water loss through transpiration (Dickison, 2000). Smaller stomata create high resistance, resulting in lower transpiration rates (Abrams et al., 1994), but the fact that phytomass production was not observed to be affected by increasing $\mathrm{Cd}$ concentrations in the present study (Figure 1) suggests that assimilation processes were not limited by carbon $\left(\mathrm{CO}_{2}\right)$ availability. Increasing stomatal density is often a response to decreasing stomatal surface areas to assure surface gas exchange and, consequently, adequate carbon influx. Increasing stomatal density and decreasing stomatal surface areas may represent anatomical leaf tolerance mechanisms in Pfaffia glomerata for controlling transpiration processes, as the regulatory efficiencies of stomata opening mechanisms are associated with stomatal size (Abrams et al., 1994).

Induced xeromorphic characteristics (in addition to the thickness of endodermis) may be important to Cd-tolerance in Pfaffia glomerata. The observed reductions in leaf water potential apparently did not constrain biomass production, and may be associated with the increased endodermis thickness and reduced water flow into the xylem vessels (Krishnamurthy et al., 2011). Decreases in transpiration rates, due to heavy metal effects on stomatal characteristics (Yang et al., 2004), and by mechanical blocking of water movements by the endodermis (Krishnamurthy et al., 2011) help preventing heavy metal movement to the upper parts of the plant, thus avoiding deleterious effects on photosynthetic sites. These same characteristics are apparently associated with the higher $\mathrm{Cd}$ concentrations encountered in the roots.

Based on significant water potential decreases and induced xeromorphic characteristics observed in leaves under $\mathrm{Cd}$-stress conditions (both indicate lower transpiration rates than seen in control plants), and absence of any differences in total biomass production, Pfaffia glomerata plants can apparently accumulate biomass at rates similar to control plants while using lower water volumes. Similar results were reported by Rossato et al. (2011) in Plucheas agittalis plants exposed to toxic lead concentrations.
Physiological features associated with Cd tolerance in Pfaffia glomerata: Plants are able to increase their antioxidant enzyme activities in order to reduce oxidative stress, thus increasing their $\mathrm{Cd}$ tolerance (Singh et al., 2006). Antioxidative defenses fall into two general classes: low molecular weight antioxidants, composed of lipid-soluble membraneassociated antioxidants ( $\alpha$-tocopherol and $\beta$-carotene) and water-soluble reductants (GSH and ascorbate), and enzymatic antioxidants (SOD, CAT, GPX, and APX) (Cao et al., 2004). The role of SOD in antioxidative defenses is to eliminate reactive oxygen species (ROS) that generate $\mathrm{H}_{2} \mathrm{O}_{2}$, with the resulting $\mathrm{H}_{2} \mathrm{O}_{2}$ being removed by CAT, APX, and GPX (Cao et al., 2004). High activity levels of these enzymes have commonly been reported in plants exposed to heavy metals (Calgaroto et al., 2010; Gupta et al., 2011).

Significant increases in lipid degradation products (MDA) were observed in the roots and leaves of $\mathrm{Cd}$ treated plants (Table 4). The increased accumulation of lipid peroxides in seedlings was indicative of enhanced production of toxic oxygen species, and lipid peroxidation may be a consequence of ROS generation. Both redox ( $\mathrm{Cu}$ and $\mathrm{Fe}$ ) and non-redox actives ( $\mathrm{Zn}$ and Cd) metal ions have been reported to increase lipid peroxidation via ROS generation in plants (Gallego et al., 1996). Cd-induced oxidative stress in sunflower leaves was observed to be mediated by ROS, as low levels of lipid peroxidation, the maintenance of GSH content, and increases in lipoxygenase activity were observed in the presence of free radical scavengers (Gallego et al., 1996).

Lipid peroxidation in roots may be a consequence of ROS generation, as was indicated by increasing SOD activity in Cd-treated plants (Dixit et al., 2001). Increases in SOD activity have been related to higher values in superoxide radical concentrations due to the synthesis of enzymes induced by superoxide-mediated signal transduction (Rossato et al., 2011). SOD represents the first line of antioxidant defense system (Mitller, 2002) and has a marked role in ROS scavenging in Pfaffia glomerata roots under $\mathrm{Cd}$ stress. We observed similar $\mathrm{Cd}$ effects on root CAT and APX activities: while increased activities were seen in roots at the highest $\mathrm{Cd}$ concentrations, both

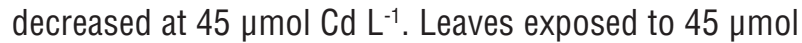
$\mathrm{Cd} \mathrm{L}^{-1}$ resulted in moderate oxidative damage (the lowest MDA levels among the Cd-treated plants), which would seem to be related to its increased Cd-PTI. Under these conditions, the low responses of APX and CAT would be compensated by increased GPX activity in this plant organ, and GPX was seen to show higher sensitivity to 
increasing ROS levels in the roots of Pfaffia glomerata. CAT and APX, in turn, appear to be activated under conditions of higher oxidative stress, since the highest activities of these enzymes were seen in roots under the biggest ROS stress.

Unlike in roots, the SOD activity of leaves did not differ in the several $\mathrm{Cd}$ treatments (Table 4), and its role in scavenging excess ROS (seen by increased MDA levels in leaves at the highest $\mathrm{Cd}$ exposures) may be performed by other ROS-scavenging enzymes found there. GPX activity once again showed responses to increased ROS levels, with its activity increasing in leaves at higher $\mathrm{Cd}$ treatments, even though the

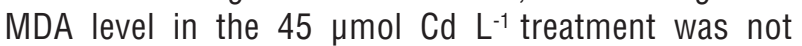
statistically different from control plants (Table 4). APX was insensitive to increasing ROS levels (the highest MDA activity was seen with the highest $\mathrm{Cd}$ treatments) and remained stable; CAT activity was not able at the same time (Table 4). The different affinities of CAT (mM range) and $\mathrm{APX}$ ( $\mu \mathrm{M}$ range) for $\mathrm{H}_{2} \mathrm{O}_{2}$ from ROS suggest that APX might be responsible for fine-tuning ROS for signaling, while CAT may be responsible for removing excess ROS during stress (Mittler, 2002).

In regards to $\mathrm{GR}$, its activity decreased in roots in response to increasing $\mathrm{Cd}$ exposure, while increasing in the leaves (Table 4). GR catalyses the NADPHdependent reduction of oxidized glutathione, and GSH (the product of this reaction) is an essential antioxidant and a substrate for phytochelatin synthesis (Dixit et al., 2001). This enzyme is responsive to different types of stress (Foyer et al., 1991), and both increases (Dixit et al., 2001) and decreases (Gallego et al., 1996) in its activity have been observed in response to $\mathrm{Cd}$ exposure. The higher GR activities seen in leaves (as observed in the present study) has been associated with its crucial role in combating oxidative stress in these tissues (Foyer et al., 1991).

In conclusion, our results demonstrated that Pfaffia glomerata has great potential for use in Cd-phytoextraction programs, being a $\mathrm{Cd}$ hyperaccumulator species, as previous proposed by Carneiro et al. (2002). The high Cd-tolerance of this species is closely related to anatomical and physiological features, including endodermal thickness, stomatal size and number, root SOD and GPX activities, and leaf GPX and CAT activities can serve as Cd-tolerance markers for this species. Due to its high $\mathrm{Cd}$-uptake and root accumulation growing Pfaffia glomerata plants in Cd-contaminated areas for subsequent medical use must be strictly avoided.

\section{ACKNOWLEDGEMENTS}

Authors are grateful to the Fundação de Amparo à Pesquisa do Estado de Minas Gerais (FAPEMIG) for their financial support.

\section{REFERENCES}

Abrams MD, Kubiske ME, Mostoller SA (1994) Relating wet and dry year ecophysiology to leaf structure in contrasting temperature tree species. Ecology 75:123-133.

Arnon DI (1949) Cooper enzymes in isolated chloroplasts. Polyphenoloxidase in Beta vulgaris. Plant Physiol. 24:1-15.

Azevedo RA, Alas RM, Smith RJ, Lea PJ (1998) Response of antioxidant enzymes to transfer from elevated carbon dioxide to air and ozone fumigation, in the leaves and roots of wild-type and a catalase-deficient mutant of barley. Physiol. Plant 104:280-292.

Baker AJM (1981) Accumulators and excluders - strategies in the response of plants to heavy metals. J. Plant Nutr. 3:643-654.

Barceló J, Vásquez MD, Poshenrieder CH (1990) Plant water relations as affected by heavy metal stress: a review. J. Plant Nutr. 13:01-37.

Beyer WF, Fridovich I (1987) Assaying for superoxide dismutase activity: some large consequences of minor changes in condition. Anal Biochem. 161:559-566.

Buege JA, Aust SD (1978) Microsomal lipid peroxidation. Methods Enzymol. 52:302-310.

Calgaroto NS, Castro GY, Cargnelutti D, Pereira LB, Conçalves JF, Rossato LV, Antes FV, Dressler VL, Flores EMM, Schetinger MRC, Nicoloso FT (2010) Antioxidant system activation by mercury in Pfaffia glomerata plantlets. Biometals 23:295-305.

Cakmak I, Horst WJ (1991) Effect of aluminum on lipid peroxidation, superoxide dismutase, catalase and peroxidase activities in root tips of soybean (Glycine max). Physiol. Plant 83:463-468.

Cao X, Ma LQ, Tu C (2004) Antioxidative responses to arsenic in the arsenic-hyperaccumulator Chinese brake fern (Pteris vittata L.). Environ. Pollut. 128:317-325.

Carneiro MAC, Siqueira J0, Moreira FMS (2002) Comportamento de espécies herbáceas em misturas de solo com diferentes graus de contaminação com metais pesados. Pesq. Agropec. Bras. 37:1629-1638.

Clark RB (1975) Characterization of phosphates in intact maize roots. J. Agric. Food Chem. 23:458-460.

Das D, Samantaray S, Rout GR (1997) Studies on cadmium toxicity in plants: a review. Environ. Pollut. 98:29-36.

De Paris F, Neves G, Salgueiro JB, Quevedo J, Izquierdo I, Rates SM (2000) Psycopharmacological screening of Pfaffia glomerata Spreng (Amaranthaceae) in rodents. J. Ethnopharmacol. 73:261-269.

Dickison WC (2000) Ecological anatomy. In: Dickison WC (ed), Integrative Plant Anatomy, pp. 295-344. Academic Press, San Diego, USA.

Dixit V, Pandey V, Shyam R (2001) Differential antioxidative responses to cadmium in roots and leaves of pea (Pisum sativum L. cv. Azad). J. Exp. Bot. 52:1101-1109.

Duke S 0, Kenyon WH (1986) Effects of dimethazone (FMC 57020) on chloroplast development. II Pigment synthesis and primary leaves. Pestic. Biochem. Physiol. 25:11-18. 
Ederli L, Reale L, Ferranti F, Pasqualini S (2004) Responses induced by high concentration of cadmium in Phragmites australis roots. Physiol. Plant. 121:66-74.

Enstone DE, Peterson CA, Ma F (2003) Root endodermis and exodermis: structure, function, and responses to the environment. J. Plant Growth Regul. 21:335-351.

Gallego SM, Benavides MP, Tomaro ML (1996) Effect of heavy metal ion excess on sunflower leaves: evidence for involvement of oxidative stress. Plant Sci. 121:151-159.

Gibson KD, Neuberger A, Scott JJ (1955) The purification and properties of delta-aminolevulinic acid dehydratase. Biochem. J. 61:618-629.

Ginocchio R, Baker AJM (2004) Metallophytes in Latin America: a remarkable biological and genetic resource scarcely known and studied in the region. Rev. Chil. Hist. Nat. 77:185-194.

Gomes MP, Marques TCLLSM, Nogueira MOG, Castro EM, Soares AM (2011) Ecophysiological and anatomical changes due to uptake and accumulation of heavy metal in Brachiaria decumbens. Sci. Agric. 68:566-573.

Gupta DK, Nicoloso FT, Schetinger MR, Rossato LV, Huang HG, Srivastava S, Yang XE (2011) Lead induced responses of Pfaffia glomerata, an economically important Brazilian medicinal plant, under in vitro culture conditions. Bull. Environ. Contam. Toxicol. 86:272-277.

Heath RL, Packer L (1968) Photoperoxidation in isolated chloroplasts. I. Kinetics and stoichiometry of fatty acid peroxidation. Arch. Biochem. Biophys. 125:189-198.

Hodges DM, Delong JM, Forney CF, Prange RK (1999) Improving the thiobarbituric acid-reactive-substances assay for estimating lipid peroxidation in plant tissues containing anthocyanin and other interfering compounds. Planta 207:604-611.

Johansen DA (1940) Plant microtechnique. McGraw-Hill, New York, USA.

Foyer C, Lelandais M, Galap C, Kunert K (1991) Effects of elevated cytosolic glutathione reductase activity on cellular glutathione pool and photosynthesis in leaves under normal and stress conditions. Plant Physiol. 97:863-872.

Kabata-Pendias A, Pendias H (2001) Trace elements in soils and plants. CRC Press, Boca Raton, USA.

Kraus TE, Mckersie BD, Fletcher RA (1995) Paclobutrazol-induced tolerance of wheat leaves to paraquat may involve increased antioxidant enzyme activity. J. Plant Physiol. 145:570-576.

Krishnamurthy P, Ranathunge K, Nayak S, Schreiber L, Mathew MK (2011) Root apoplastic barriers block $\mathrm{Na}^{+}$transport to shoots in rice (Oryza sativa L.). J. Exp. Bot. 62:4215-4228.

Lawson T, James W, Weyers J (1988) A surrogate measure of stomatal aperture. J. Exp. Bot. 49:1397-1403.

Lunácková L, Sottníková A, Masaroviscová E, Lux E, Stresko V (2003/4) Comparison of cadmium effect on willow and poplar in response to different cultivation conditions. Biol. Plant. 47:403-411.

Lux AA, Sottniková A, Opatrná J, Greger M (2004) Differences in structure of adventitious roots in Salix clones with contrasting characteristics of cadmium accumulation and sensitivity. Physiol. Plant. 120:537-545.

Marchial L, Leita L, Martin M, Peressotti A, Zerbi G (1996) Physiological responses of two soybeans cultivars to cadmium. J. Environ. Qual. 25:562-566.

Marchioretto MS, Miotto STS, Siqueira JC (2010) 0 gênero Pfaffia Mart. (Amaranthaceae) no Brasil. Hoehnea 37:461-511.
Mazhoudi S, Chaoui A, Ghorbal S, El-Ferjani E (1997) Response of antioxidant enzymes to excess cooper in tomato (Lycopersicon esculentum Mill.). Plant Sci. 127:129-137.

Mittler R (2002) 0xidative stress, antioxidants and stress tolerance. Trends Plant Sci. 7:405-410.

Monni S, Uhlig C, Junttila O, Hansen E, Hynynen J (2001) Chemical composition and ecophysiological responses of Empetrum nigrum to aboveground element application. Environ. Pollut. 112:417-426.

Montanari Jr I (1999) Aspectos do cultivo comercial do ginseng brasileiro (Pfaffia glomerata (Spreng) Pedersen). In: Boletim Agroecológico 12 Centro Pluridisciplinar de Pesquisas Químicas, Biológicas e Agrícolas, Universidade Estadual de Campinas, Brasil.

Moral R, Gomez I, Navarro P, Matrix J (1994) Effects of cadmium on nutrient distribution, yield and growth of tomato grown in soilless culture. J. Plant Nutr. 17:953-962.

Nakano Y, Asada K (1981) Hydrogen peroxide is scavenged by ascorbate-specific peroxidase in spinach chloroplasts. Plant Cell Physiol. 22:867-880.

Nascimento EX, Mota JH, Vieira MC, Zárate NAH (2007) Pfaffia glomerata (Spreng.) Pedersen and Plantago majorL. biomass production in single culture and intercropped. Cienc. Agrotecnol. 31:724-730.

Oliveira F, Akisue G, Akisue M (1980) Contribuição para o estudo para 0 estudo farmacognóstico do Ginseng brasileiro, Pfaffia paniculata (Martius) Kuntze. An. Farm. Quimica 20:261.

Paiva HN, Carvalho JG, Siqueira JO (2000) Efeito de Cd, Ni, Pb e Zn sobre mudas de cedro (Cedrella fissilis Vell.) e de ipê-roxo (Tabebuia impetiginosa (Mart.) Standley) em solução nutritiva. Rev. Árvore 24:369-378.

Pence NS, Larsen PB, Ebbs SD, Letham DLD, Lasat MM, Garvin DF, Eide D, Kochian LV (2000) The molecular physiology of heavy metal transport in the Zn/Cd hyperaccu-mulator Thlaspi caerulescens. Proc. Nat. Acad. Sci. USA. 97:4956-4960.

Poschenrieder CH, Barceló J (1999) Water relations in heavy metal stressed plants. In: Prasad MNV, Hagemeyer J (eds), Heavy metal stress in plants from molecules to ecosystem, pp. 207-229. Springer Verlag, Berlin.

Rossato LV, Nicoloso FT, Farias JG, Cargnelluti D, Tabaldi LA, Antes FG, Dressler VL, MorschVM, Schetinge MRC (2011) Effects of lead on the growth, lead accumulation and physiological responses of Pluchea sagittalis. Ecotoxicol. 7:01-13.

Sandalio LM, Dalurzo HC, Gómes M, Romero-Puertas MC, Del Rio LA (2001) Cadmium-induced changes in the growth and oxidative metabolism of pea plants. J. Exp. Bot. 52:2115-2126.

Sandmann G, Böger P (1983) Comparison of the bleaching activity of norflurazon and oxyfluorfen. Weed Sci. 31:338-341.

Sharma RK, Agrawal M (2006) Single and combined effects of cadmium and zinc on carrots: uptake and bioaccumulation. J. Plant Nutr. 29:1791-1804.

Singh RP, Tripathi RD, Sinha SK, Maheshwari R, Srivastava HS (1997) Response of higher plants to lead contaminated environment. Chemosphere 34:2467-2493.

Singh S, Eapen S, D'Souza SF (2006) Cadmium accumulation and its influence on lipid peroxidation and antioxidative system in an aquatic plant, Bacopa monnieri L. Chemosphere 62:233-241.

Skrebsky ET, Tabaldi LA, Pereira LB, Rauber R, Maldaner J, Cargnelutti D, Gonçalves JF, Castro GY, Shetinger MRC, Nicoloso FT (2008) Effect of cadmium on growth, micronutrient concentration, and d-aminolevulinic acid dehydratase and acid phosphatase activities in plant of Pfaffia glomerata. Braz. J. Plant Physiol. 20:285-294. 
Soares CRFS, Siqueira J0, Carvalho JG, Moreira FMS (2005) Fitotoxidez de cádmio para Eucalyptus maculata e E. urophylla em solução nutritiva. Rev. Árvore 29:175-183.

Souza IRP, MacAdam JW (1998) A transient increase in apoplastic peroxidase activity precedes decrease in elongation rate of B73 maize (Zea mays L.) leaf blades. Physiol. Plant 104:556-562.

Van Assche F, Clijsters H (1990) Effects of metals on enzyme activity in plants. Plant Cell Environ. 13:195-206.

Wójcik M, Vangronsveld J, D'Haen J, Tukiendorf A (2005) Cadmium tolerance in Thlaspi caerulescens. Environ. Exp. Bot. 53:163-171.
Yang XE, Ye HB, Long XX, He B, He ZL, Stoffela PJ, Calvert DV (2004) Uptake and accumulation of cadmium and zinc by Sedum alfredii Hance at different $\mathrm{Cd} / \mathrm{Zn}$ supply levels. J. Plant Nutr. 27:1963-1977.

Zhao FJ, Lombi E, Mcgrath SP (2003) Assessing the potential for zinc and cadmium phytoremediation with the hyperaccumulator Thlaspi caerulescens. Plant Soil 249:37-43.

Zhu YL, Zyaed AM, Qian JH, Souza M, Terry N (1999) Phytoaccumulation of trace elements by wetland plants: II. Water hyacinth. J. Environ. Qual. 28:339-344. 